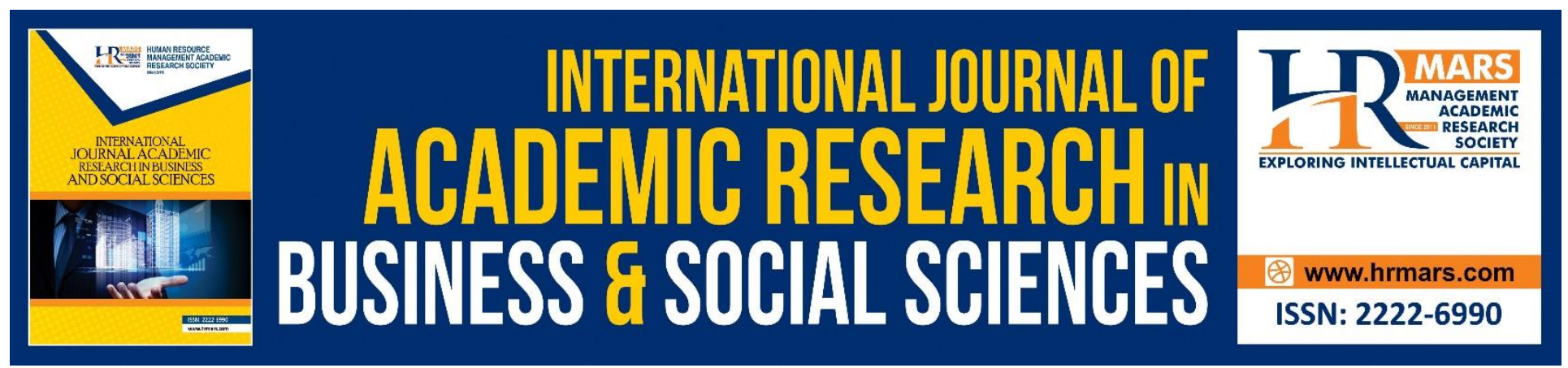

\title{
EFL Learners' Needs in Preparatory Schools and Supplementary Techniques to Improve Their Language Proficiency
}

\author{
Yunus Yildiz
}

To Link this Article: http://dx.doi.org/10.6007/IJARBSS/v9-i1/5460

DOI: $10.6007 /$ IJARBSS/v9-i1/5460

Received: 19 Dec 2018, Revised: 11 Jan 2019, Accepted: 25 Jan 2019

Published Online: 01 Feb 2019

In-Text Citation: (Yildiz, 2019)

To Cite this Article: Yildiz, Y. (2019). EFL Learners' Needs in Preparatory Schools and Supplementary Techniques to Improve Their Language Proficiency. International Journal of Academic Research in Business and Social Sciences, 9(1), 586-596.

Copyright: (C) 2019 The Author(s)

Published by Human Resource Management Academic Research Society (www.hrmars.com)

This article is published under the Creative Commons Attribution (CC BY 4.0) license. Anyone may reproduce, distribute, translate and create derivative works of this article (for both commercial and non-commercial purposes), subject to full attribution to the original publication and authors. The full terms of this license may be seen

at: http://creativecommons.org/licences/by/4.0/legalcode

Vol. 9, No. 1, 2019, Pg. 586 - 596

http://hrmars.com/index.php/pages/detail/IJARBSS

JOURNAL HOMEPAGE

Full Terms \& Conditions of access and use can be found at http://hrmars.com/index.php/pages/detail/publication-ethics 


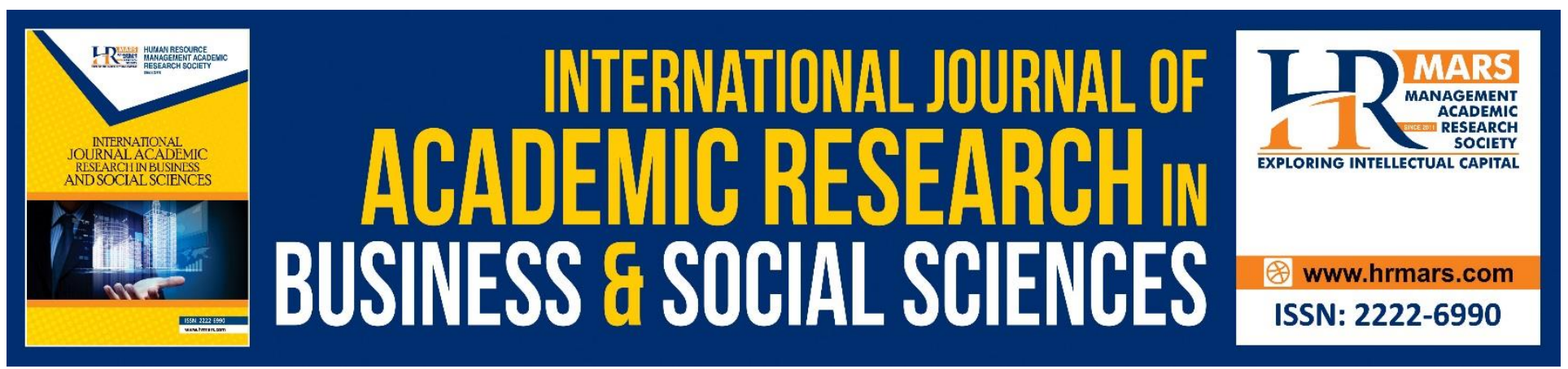

\title{
EFL Learners' Needs in Preparatory Schools and Supplementary Techniques to Improve Their Language Proficiency
}

\author{
Yunus Yildiz \\ ${ }^{1}$ Education Faculty, Department of Languages, Tishk International University, Erbil, Iraq \\ Correspondence: Yunus Yildiz, Education Faculty, Department of Languages, Tishk International \\ University, Erbil, Iraq \\ Email:yunus.yildiz@ishik.edu.iq, yenigunler@yahoo.com
}

\begin{abstract}
Teaching English in a proficiency level and as a formal language to EFL learners is a big challenge in a non-English speaking country. This challenge might go on to some extent because of the curriculum in which students only learn basic rules and general English language skills in an intensive period of time. Preparatory schools of English language based universities usually have this kind of unique condensed program to improve language learners' acquisition. However, students need more than the curriculum in order to study in their departmental studies at ease. This article demonstrates an explanation why preparatory school graduates are still weak in speaking and writing skills although they complete one year intensive language course. In this context, comparing one class of 20 civil engineering department students' English knowledge, who have completed one year language education and started to take their most subjects in English, and 47 mixed A1 and B1 (due to CEFR) level groups of English language prep school learners' replies to the research questions about feelings and expectations on learning English may provide healthy data to learn about learners' needs and to improve the Preparatory School education system. In this study, civil engineering department students study departmental subjects in English, academic English and technical English, but the students of the preparatory school only learn general English.
\end{abstract}

Keywords: language skills, acquisition, EFL learner, preparatory school graduates, general English, curriculum, proficiency level

\section{Introduction and Literature Review}

Hudelson (1989a) says that ' 25 years ago, the common belief in language teaching was not to worry about young learners' writing until they have mastered the oral language.' We should teach children to understand and to speak the language first. Language develops in sequence from listening to 
speaking, then to reading, and finally to writing. Writing is the last of the language processes to develop, and it is the hardest for children to master. Therefore, writing is the last skill to be delivered. Elementary EFL and ESL teachers ought to concentrate on developing children's speaking vocabularies and not focus on literacy. Working in a private university as an EFL teacher, an advanced English course lecturer who teaches English to the first year students in the civil engineering department and at the same time general English to the students of the preparatory school of the private university, it is necessary to say that there is such a huge gap regarding students' language level in the field of speaking and writing at the civil engineering department. Engineering students who have graduated from the preparatory school need a lot of work for their weak English language. In fact, most of those students had English lessons starting from the fourth grade till the twelfth grade in their schools before they studied in the preparatory school. However, the statement that civil engineering students of the first year is: "If we study civil engineering subjects in our own language, we might get perfect full marks in the exams." This reply which comes from the engineering students who have had intensive general English course previously (total 625 hours, 24 weeks), demonstrates that other departments' students might be complaining about the same issue.

Hudelson (1989b) indicates that 'parents of second language learners are largely concerned about their child's improvement; they ask about progress.' This is still true for the university level students who are taking their education in the prep school in Iraq. There are some curious and concerned parents that come to prep school to pick up information about their child's progress. Keeping the students' writings and demonstrating them to parents to see the collection of writing samples of their children, help the learners to develop of their writing skills and provides a support bridge that comes from the families. This is actually followed while students are taking the course and the results are kept. Some language preparatory schools, to find out the students' language level, request the new comers to write a paragraph or a composition and/or to speak about one specific topic for some time. This is really a good technique, at least, it is not time consuming like the big detailed international exams. The teachers may check learners'grammar and vocabulary on the sheets. However, formal institutions have to demonstrate the students' level by original, worldly famous tests like Cambridge, Oxford or Pearson placement and proficiency tests as a proof to persuade the exam takers and the stakeholders.

In order to have good English language learners, there should be many steps to follow. The first step is the responsibility to figure out how to build up the students' skills and where exactly the weak spots they have. From that perspective, the real work of teachers is that of functioning as instinctive pride builders in the classroom. Bowman (2011) states that: 'Productive teachers are adept at getting students to anticipate how proud they will be when their behavior or achievements ultimately mirror class and societal teachers are not just teaching the students the materials, they also, teach principles, disciplines, values, and moralities. For those reasons, they are leaders who are working to make their students as perfect as possible.' Schlechty (2002) says that "The primary function of a leader is to inspire others to do things they might otherwise not do and encourage others to go in directions they may not otherwise pursue." The students have also responsibilities like teachers, though they get these responsibilities from their teachers such as homework, classwork, and any other activities. During the period of time teaching at the university, it has been noticed how the female students are more active than the boys. Iflazoglu \& Hong (2012) point out that "Girls, in 
general, tend to hold more positive attitudes towards homework, manifesting responsibility and persistence, with higher motivation to complete homework than boys. Girls budget time, organize their homework regularly and work in a certain order towards completion of homework, whereas boys prefer to work in batches or at the last minute." According to Tosun and Yildiz (2015), there have been many students that wander around with a pale soul (unmotivated) and aimlessly. There are many reasons why the new generation is wandering like that. One of the main reasons as Yildiz (2018) states, can be students' addiction to social media and their technological devices. They have been the slaves of their electronic toys. Social media is generally used on a regular basis by millions of people across the globe for different reasons (Tzotzou, 2014). A big portion of social media users is made up of youths where most of them are college students. In fact, a recent survey of 3000 students from across the US shows that $90 \%$ of college students use Facebook and $37 \%$ use Twitter (Dahlstrom et al., 2011). This fact is more or less the same for the students in Iraq.

Based on this reality above, learners of a foreign language must work hard regularly to develop their knowledge and need language practising environment to gain proficiency. It is obvious that this formula is valid for any language learners to learn something new. Teaching and learning theories have been changing from institutions to institutions. For example, when people travel abroad to reach their education goals doing degree, they come across new methods or approaches of education. The common toughest issue while studying in a foreign country or in a foreign language education system is students' getting difficulty to learn the new language due to provided wrong learning strategies. The development of the English language has been active in many developing countries. For example, private or non-profit universities are good examples to address here in Iraq that English language is the main language for teaching in most of the scientific studies of the universities. Thankfully, nowadays, teaching scientific subjects compulsorily in English language at university settings has become more popular and easier. EFL learners as learning such a language in the English environment, will be exposed to new values and approaches of the native speakers, whose language and culture have been habitual for them. There are many reasons that universities use English language in teaching more than other languages. The first reason is that, as long as the English language is the most common language in the world, it is the way to communicate between lecturers and students. The second reason is the diversity among the students that being from different parts of the world makes English the easiest language to learn and the medium language to communicate. The third and the most important reason is that English language is used in most sources around the world. For the reasons above, universities in the foreign language curriculum have stipulated the language preparatory school to improve the student's language skills prior to starting the academic studies.

Today, it is a miracle to come across highly motivated and aimed students because what students are interested is mostly their untouchable social media and this interest usually turns the learners to introvert characters. Therefore, having little motivation toward learning spoken English brings a low level of oral English. Many EFL teachers in this private university preparatory school and the continuing education centre (due to mutual conversations and interviews) believe that students are more interested in studying spoken English than studying written English because spoken English is the main problem of the learners in real communication. Studying English mainly based on the grammar and vocabulary memorization is not what the EFL learners demand (due to mutual 
conversations and interviews with students) but learning the spoken language do. River (2018a, p94) states that 'In many foreign-language classrooms in the early part of the twentieth century, emphasis was placed on the intellectual aspect of language learning.' The new and more useful method of teaching language is the teaching of oral language (spoken-language) for many reasons, regarding peoples' interest in technology, movies, internet, songs, chatting, etc. Hence, it would be much easier to teach them the language based on what they love and care about. River (2018b, p94) emphasizes that 'In a revolution of language teaching methods, the major emphasis swung to the early cultivation of the speaking skill. Students were to be taught from ... They would thus be able to construct many useful sentences orally before they had a clear understanding of the systematic operation of the language.'

\section{Methodology}

First year civil engineering students (20 members) are informed about this research and are asked about their understanding performance related to core subjects which are presented in English in their department during the academic year and beside this, two different language levels of civil engineering prep school students (total 47 students) are given general English course in 24 weeks throughout the academic year and informed about the survey questions after two months academic year commences. The aim is explained to these different level learners by the researcher. Both level students' survey replies have been demonstrated in the graphs. This article demonstrates an explanation of what the language learners need, comparing 20 students in the first grade of civil engineering with additional English language courses in their departments, and 47 students of the language preparatory school students' needs. While civil engineering students are dealing with particular terms and academic English, the students in the preparatory school learn general English. The instructor is the same for all three groups. Class observation, interview and survey questions techniques are used as the qualitative and quantitative approaches to save the data.

The reason of this questionnaire (which is shown in the appendix A) is to discover the students' reaction to the English language, subjects, teaching methods, and instructors. This questionnaire statements are in three categories and given to 47 language preparation course students. The two groups are in two language levels according to Common European Framework of Reference.The researcher submits the questionnaire upon the first level is a low level named (A1) in CEFR while the second level is an upper level named (B1) in CEFR. These group students are going to study at the civil engineering department the following year, so it is extremely important to focus on the language skills right now. Otherwise, they probably will face some language proficiency drawbacks. As it is mentioned above, there are three parts in the student questionnaire, all of which are presented with multiple choices. In the first part of the questionnaire, the students are asked many questions, and the first question is under the title "Why am I learning English...." In the second part of the questionnaire, the students are asked also different questions, and those questions are under the heading "How do you feel about English lessons?" In the third part of the questionnaire, the students are asked different questions, and those questions are under the title "What is your feeling about learning English?" Therefore, this paper is divided into two parts. The first one is the questionnaire which was submitted to students in different levels of the preparatory school, and the second one is 
INTERNATIONAL JOURNAL OF ACADEMIC RESEARCH IN BUSINESS AND SOCIAL SCIENCES

Vol. 9, No. 1, Jan, 2019, E-ISSN: 2222-6990 (C) 2019 HRMARS

the list of solutions that EFL teachers might use to close the language gap and to improve the students' levels.

\section{Results}

The results of the questionnaire in this study, exhibit that the participants are more motivated to get good grades in English written exams rather than to be able to speak English. To get such a result was expectable because the main reason they are learning English is to do well in their academic studies and at the same time it is the university requirement to pass the preparatory school before starting their majors. The reasons might be as Rivers (2018) says "The native language as learned behavior was acquired by the infants in spoken form first, and this led to the assumption that students will acquire a second language more easily if it is presented in the spoken form before the written form. This notion seemed even more self-evident to the early structural linguists because many of the languages they were studying did not exist in the written form, or possessed very little written literature."

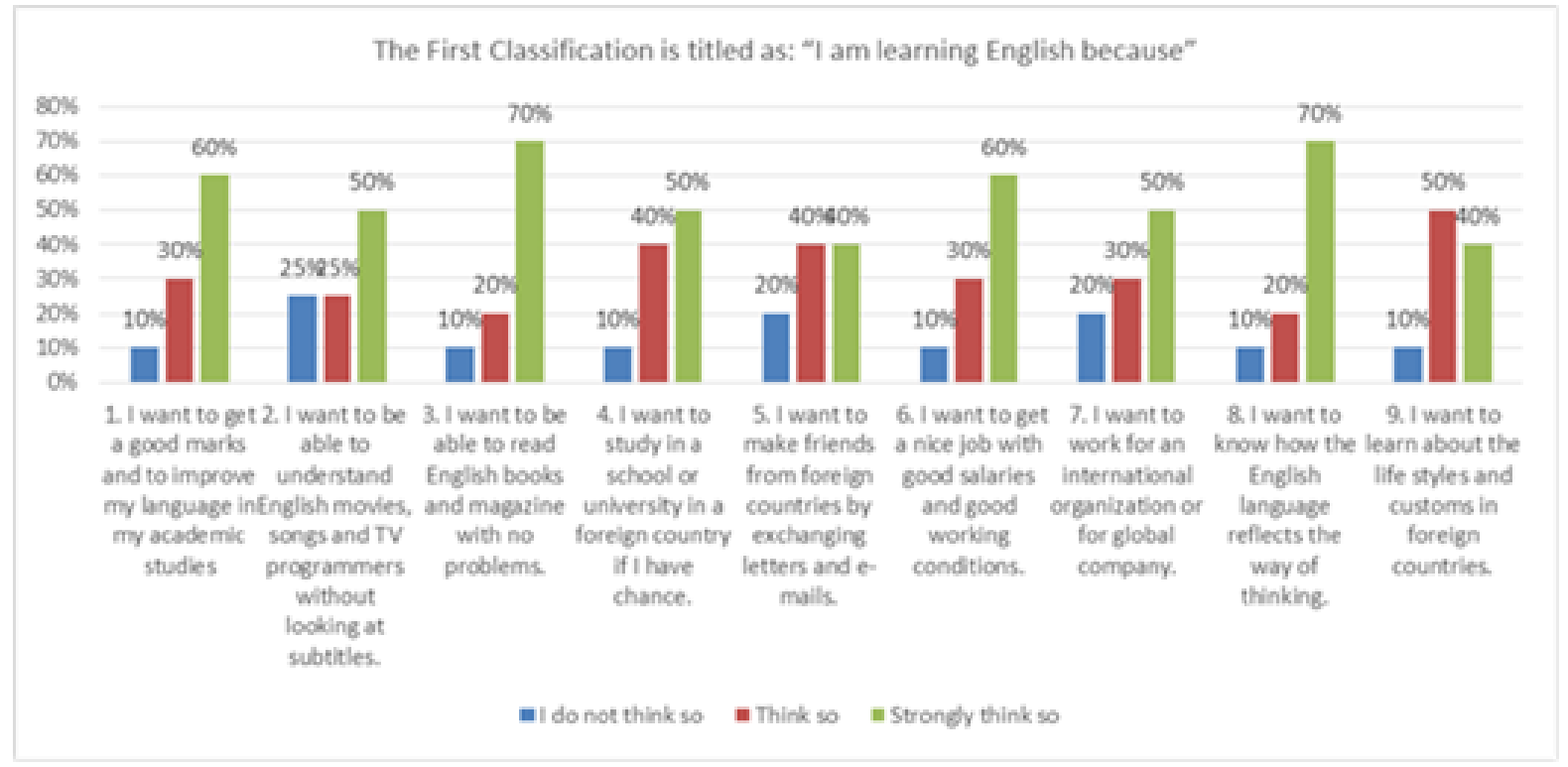

Chart 1: "I am learning English because" from A1 (22) students.

From the first chart we can read that A1 level students learn English to get good marks in their academic studies which comes for the next year, would like to be proficient in understanding the course book texts for their major, to study abroad, to get a well-paid job and to understand the way how other people live by their studies. 
INTERNATIONAL JOURNAL OF ACADEMIC RESEARCH IN BUSINESS AND SOCIAL SCIENCES

Vol. 9, No. 1, Jan, 2019, E-ISSN: 2222-6990 @ 2019 HRMARS

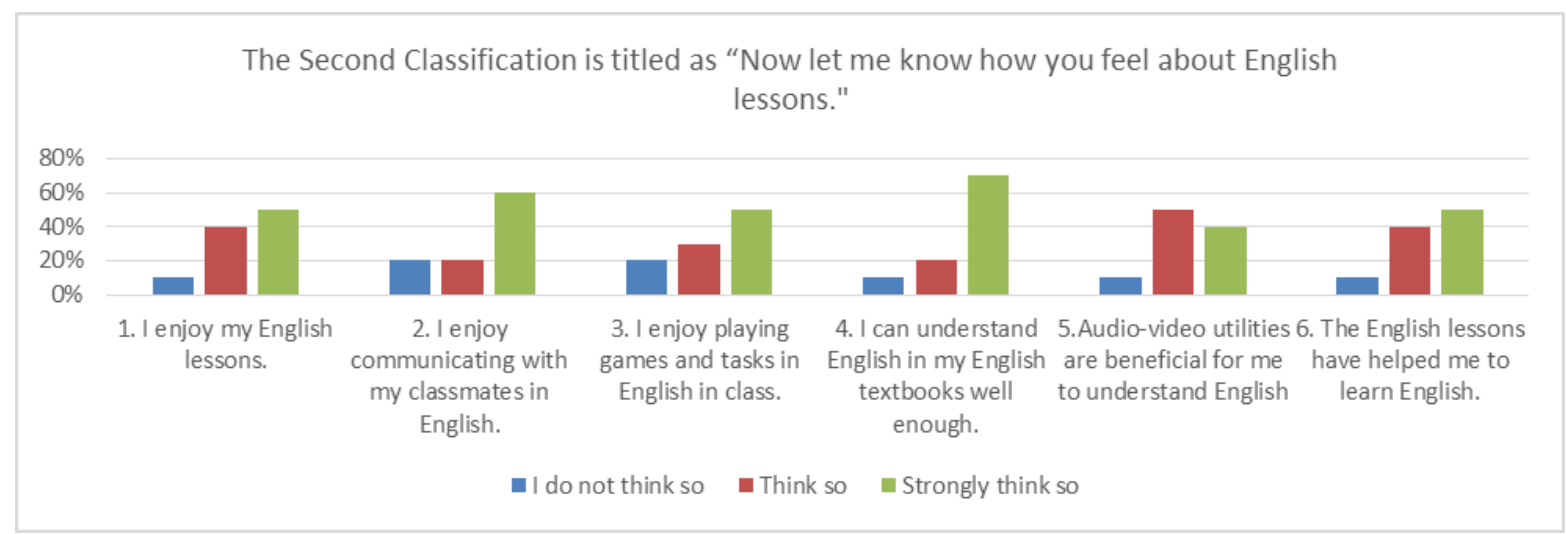

Chart 2: "Now let me know how you feel about English lessons." from A1 (22) students.

From the second chart, we can see that A1 level students are satisfied with the teaching system, and they mostly feel good about English lessons.

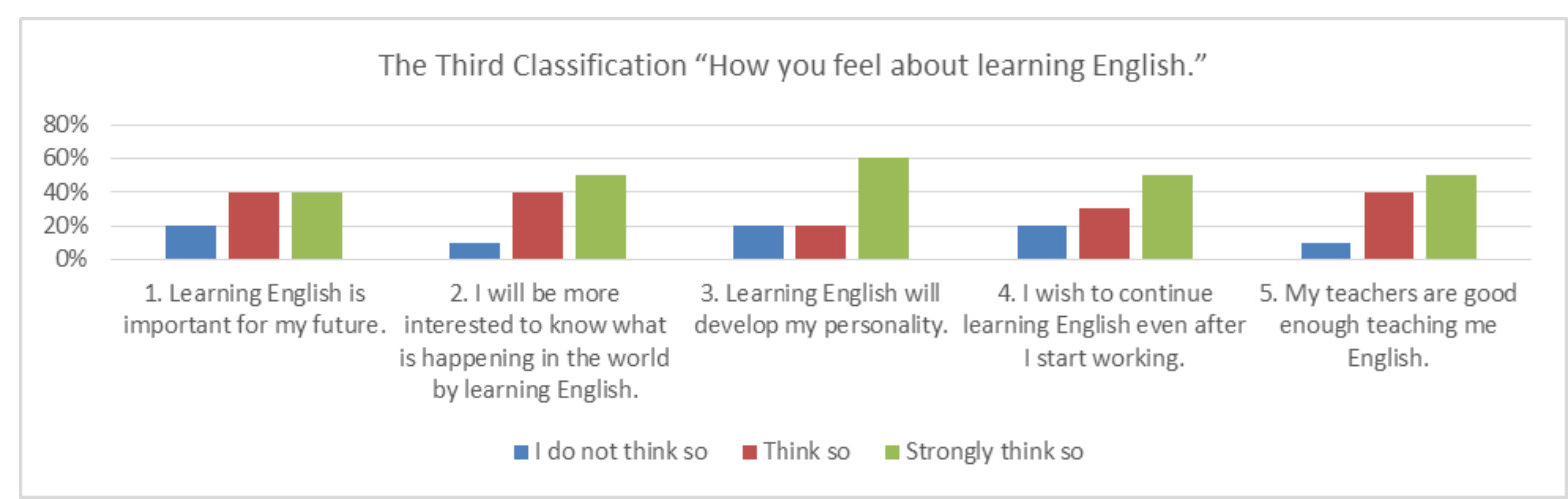

Chart 3: "How do you feel about learning English?" from A1 (22) students.

From the third chart, we can understand that A1 students feel the importance of English, are interested in keeping up learning the world with English and think that their personalities are developed by learning English. 
INTERNATIONAL JOURNAL OF ACADEMIC RESEARCH IN BUSINESS AND SOCIAL SCIENCES

Vol. 9, No. 1, Jan, 2019, E-ISSN: 2222-6990 (C) 2019 HRMARS

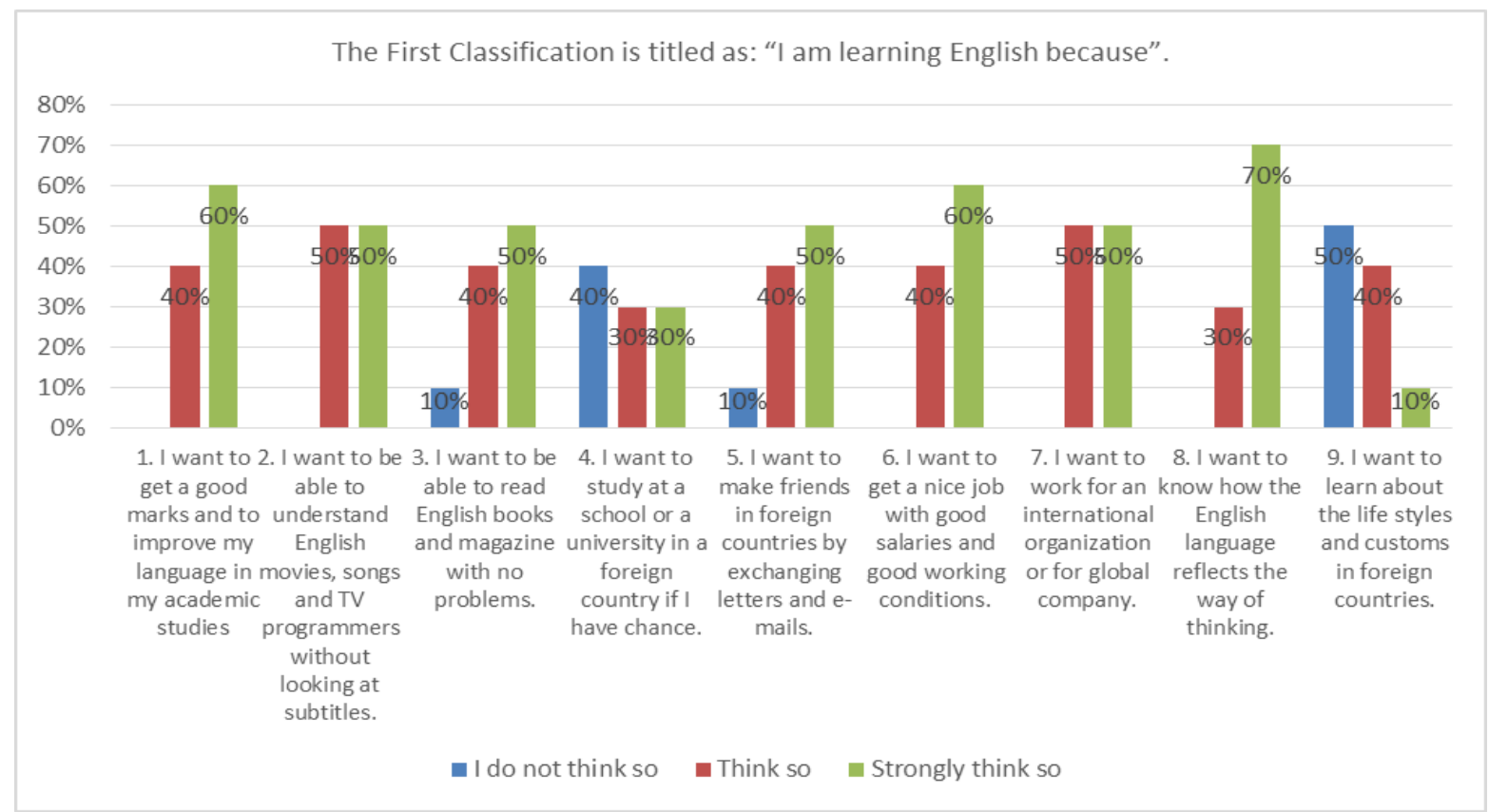

Chart 4: "I am learning English because" from B1 (25) students.

From the fourth chart, we can read that B1 level students learn English to get good marks in their academic studies which comes for the next year, would like to be proficient in understanding the course book texts for their major, but not interested in to studying abroad, to make friends in abroad, to get a well-paid job, but they are not interested in other cultures.

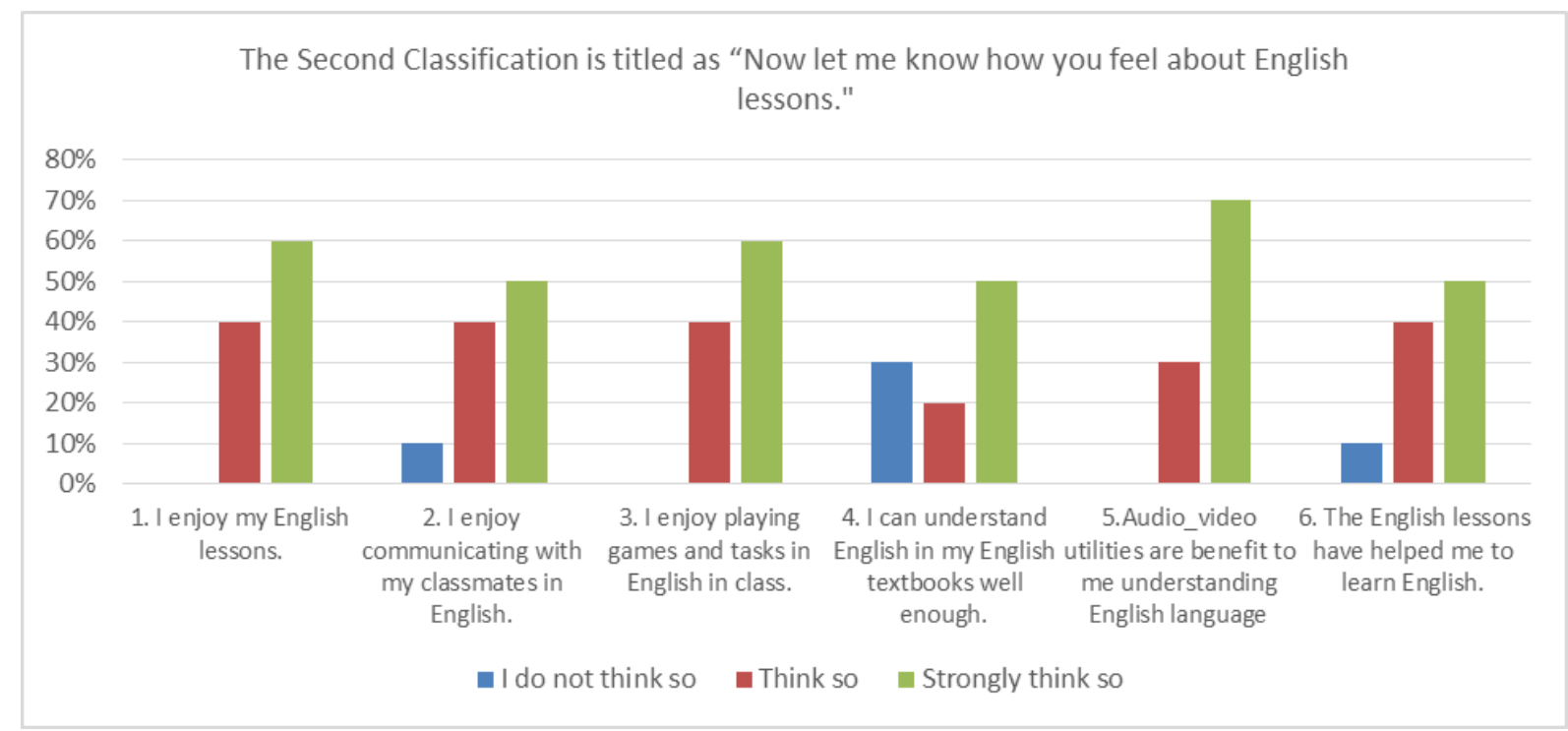

Chart 5: "Now let me know how you feel about English lessons?" from B1 (25) students.

In the fifth chart, more or less B1 level students feel the same about English lessons except a large number of students feel the textbooks a bit difficult to understand. 
INTERNATIONAL JOURNAL OF ACADEMIC RESEARCH IN BUSINESS AND SOCIAL SCIENCES Vol. 9, No. 1, Jan, 2019, E-ISSN: 2222-6990 @ 2019 HRMARS

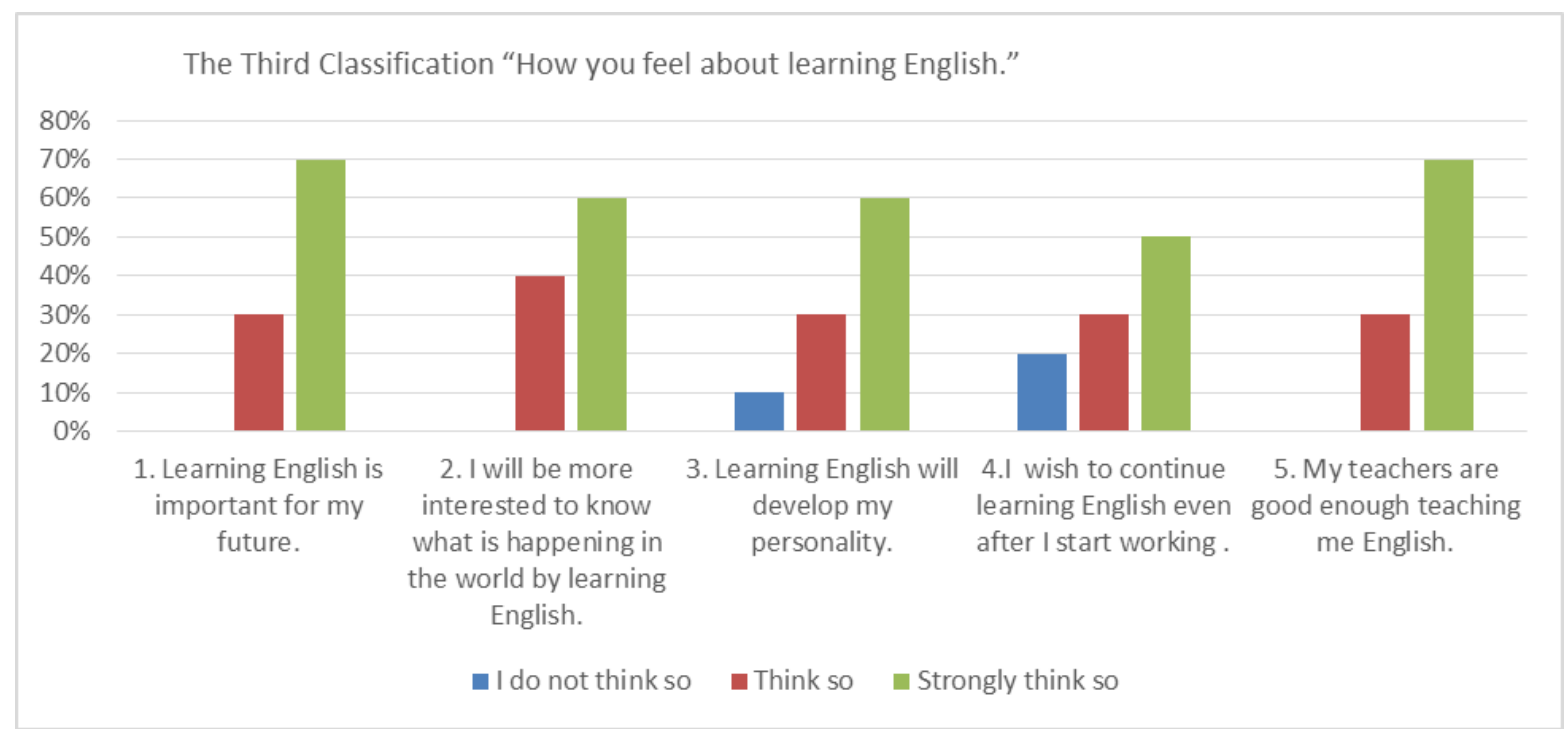

Chart 6: "How do you feel about learning English." from B1 (25) students.

In chart 6, it can be said that students are content with the teachers and they find learning English very important for their career.

\section{Discussion and Recommendation}

Inspecting the students' final exam (which include all language skills) results after 625 hours intensive English course, we can claim that teaching students primarily how to take notes is one of the important solution to improve the students' writing skill in the preparatory school. Many students in the Civil Engineering department do not know how to take notes, that most of them cannot answer the critical questions in the exams. Taking notes starategy was experinced within B1 class, and noticed that learners' listening skill has improved rapidly. Santeusanio (1991) citing in Coman and Heavers (1991) says that "Whether you consider yourself a skilled or unskilled note taker, your notes taking can improve. You can learn to be more flexible and concise." Therefore, the more students are exposed to do tasks, the more they get better.

Another solution to improve the students' language skills is to pay a visit to the school library. University students usually use the library only as a quiet place to study or to share information. They are allowed to use the book in the library but not to borrow books to take home. The students should have their own account to borrow books from the library. It is a great way to escalate their knowledge. Barrass (2005) thinks that "No one can read a good and interesting book for an hour without being better for it; happier and better, not merely for the moment, but the memory remains ..." That is why, students should be allotted to hold a book for a week at least to get much benefit. Lastly but not least, regarding to improve the students' language proficiency, there must be activities to follow to motivate and to make them involve in the university community. Obviously, learning does not appear at once, it needs a long process. For the teachers to teach students to learn English during class time is the obligatory work, but for some students that teaching might be insufficient and they may need some extra care voluntarily. Here extracurricular activities might be the best remedy to change the learners' learning ways. To deal with the weak students who need extracurricular English activities, various activities should be arranged to their needs (Furner et al, 
2005), since some learners might learn English better in visual, oral, listening or/and motor activities (Richards \& Schmidt, 2013). Educators formally teach learners according to given curriculum and/or whatever they are requested to teach. Therefore, the outcomes must be mentioned or handed in a paper beforehand to freshmen clearly on the very first day of the school (Yildiz, 2017). Moreover, teachers should be among students while these extracurricular activities are followed in order to set an English atmosphere. One of the greatest ways to make learners involve is by having students clubs and associations. Such clubs will keep the students to be involved and familiarized with the environment of the university. In addition, clubs are a great place to make friendships among the students. The schedule of the clubs should be arranged with the intention of creating a setting where the students may be engaged in activities they normally enjoy in the native language or sharing the kinds of activities their counterparts enjoy in the foreign culture. We might use the idea of joining clubs by arranging the students based on their interests. For instance, English language clubs, football clubs, books club, music club, civil engineering students clubs, information technology club, etc. Such clubs can improve the students' language proficiency and at the same time, they can engage with other students in their area of interests. The civil engineering students in the preparatory school can join the club of civil engineering, so they may enjoy the time and gain formation.

In conclusion, there are many students who study at civil engineering department of this university, are not able to understand the language adequately. Due to the fact that those students attended 625 hours intensive language course at the language preparatory school of the university. Thus, there is a necessity to write this article to find out solutions to fill the gap with new techniques among the students whose English language level is not proficient to go on their studies in the departmental subjects.

\section{Acknowledgments}

I would like to give my gratitudes to the Tishk International University Prep School principal and the students of the school because during this research I needed deep assistance and they have supported me much enough to collect necessary data.

\section{References}

Barrass, R. (2005). Students must write: a guide to better writing in coursework and examinations, Routledge.

Bowman R. (2011). Rethinking What Motivates and Inspires Students, The Clearing House: A Journal of Educational Strategies, Issues and Ideas, Volume 84(6), 264-269.

Dahlstrom, E., de Boor, T., Grunwald, P., \& Vockley, M. (2011). ECAR: National study of undergraduate students and information technology. Retrieved September 8, 2018, from http://net.educause.edu/ir/library/pdf/ERS0908/ERS0908W.pdf

Furner, J. M., Yahya, N., \& Duffy, M. L. (2005). Strategies to reach all students. Intervention in School and Clinic, 41(1), p. 16-23

Hudelson, S. (1989ab) Write On: Children Writing in ESL. ERIC Clearinghouse on Languages and Linguistics, Washington, D.C. Pages 1 and 92. 
INTERNATIONAL JOURNAL OF ACADEMIC RESEARCH IN BUSINESS AND SOCIAL SCIENCES

Vol. 9, No. 1, Jan, 2019, E-ISSN: 2222-6990 @ 2019 HRMARS

Iflazoglu A. \& Hong E. (2012) Relationships of Homework Motivation and Preferences to Homework Achievement and Attitudes in Turkish Students, Journal of Research in Childhood Education, Volume 26(1), 57-72.

Richards, J. C., \& Schmidt, R. W. (2013). Longman dictionary of language teaching and applied linguistics. London: Routledge

Rivers W. M. (2018). Teaching foreign language skills, University of Chicago Press.

Santeusanio, Richard P. (1991). Classroom Materials: How to Improve Your Study Skills by Marcia J. Coman and Kathy L. Heavers. Blackwell Publishing Ltd. Journal of Adolescent \& Adult Literacy, Volume 34(8), P.673

Schlechty, Phillip C. (2002). Working on the Work: An Action Plan for Teachers, Principals, and Superintendents. The Jossey-Bass Education Series.

Tosun M. \& Yildiz Y. (2015). The Role of Moral Values and Systematic Informing in Aim-Based Education. International Journal of Social Sciences \& Educational Studies, Volume 2(2), 40-44.

Tzotzou, M. D. (2014). Designing a Set of Procedures for the Conduct of Peer Observation in the EFL Classroom: A Collaborative Training Model towards Teacher Development. Multilingual Academic Journal of Education and Social Sciences, 2(2), 15-27. https://doi.org/10.6007/majess/v2-i2/1387

Yildiz, Y. (2017). Extracurricular Activities in the Steps of Aim-Based Education. International Journal of Social Sciences \& Educational Studies, Volume 4(2), 129-135.

Yildiz, Y. (2018). Social Media Addicted Students' Failure in Learning a Foreign Language. Proceedings of the IRES International Conference, Krakow, Poland, 4th-5th October 2018, P.7-10. 